\title{
O BIOPODER NA PERSPECTIVA FOUCAULTIANA
}

BIOPOWER IN PERSPECTIVE FOUCAULTIAN

IL BIOPOTERE IN PROSPETTIVA DI FOUCAULT

Edimar Inocêncio Brigido*

\section{RESUMO}

Este trabalho discute as principais características do Biopoder enquanto forma de organização social, sendo uma ação múltipla de inúmeros poderes que atuam no plano biológico. Procurase, a partir da filosofia foucaultiana, explicitar uma análise do poder, traçando o deslocamento da temática entre a modernidade e a contemporaneidade. Pretende-se, por fim, chamar a atenção do leitor para o poder disciplinar, caracterizando as suas técnicas na formação de corpos dóceis, possibilitando uma conformação do biopoder entre a disciplina e a regulamentação dos corpos sociais.

PALAVRAS-CHAVE: Biopoder. Disciplinalização. Regulamentação. Organização social. Corpos dóceis.

\begin{abstract}
This paper discusses the main features of Biopower as a form of social organization, being a multiple action of many powers that act on the biological level. Wanted, from Foucault's philosophy, explicit analysis of power, tracing the movement of the subject between modernity and the contemporary. It is intended to eventually draw the reader's attention to the disciplinary power, characterizing their techniques in the formation of docile bodies, enabling a conformation of bio-power between discipline and regulation of social
\end{abstract}

KEYWORDS: Biopower. Disciplining. Regulation. Social organization. Docile bodies.

\section{SOMMARIO}

Il documento analizza le principali caratteristiche di Biopower come una forma di organizzazione sociale, essendo un azione multiplo di numerosi poteri che operano in termini biologici. Si cerca di spiegare l'analisi tracciando il passaggio di potere da ciò che era a quel

\footnotetext{
* Doutorando em Filosofia pela PUCPR. Professor de Ética no UNICURITIBA.

E-mail: edimarbrigido@ hotmail.com.
} 
che è generato in epoca contemporanea. Esso è destinato a richiamare l'attenzione sul potere disciplinare che lo caratterizza, e le sue tecniche nella formazione di corpi docili, permettendo una conformazione di bio-potere tra disciplina e regolamentazione.

PAROLE CHIAVE: Biopower. Disciplinare. Regolamento. L'organizzazione sociale. Corpi docili.

\section{INTRODUÇÃO. Do poder de tirar a vida ao poder de mantê-la}

O poder sempre se fez presente em sua magnitude, perceptível ou não, para analisar, controlar, vigiar, castigar e enquadrar no sistema aquele que por alguma razão corrompeu as leis aplicadas sem nenhuma barreira à comunidade. A dimensão temporal assinala na história do poder um traço eminentemente expressivo no que tange às suas mudanças de se impor, caracterizar, acomodar, tornar-se invisível ou visível, individualizar e multiplicar. Essa permeabilidade que por ora pôde ser reconhecida como advinda do alto, agora se faz proveniente de todos os lados possíveis da sociedade, esta, como que num tratado inconsciente confirma a cada dia sua relação de submissão com o poder.

A grande característica do poder é sua invisibilidade que não afeta nem um pouco sua ação sobre a vida do homem. O poder age como que "personificado", seja em forma de leis, autoridade, capital e tantas outras formas de dominação que são exercidas na coletividade e que aparentam serem únicas. Nesse sentido, o poder se encontra em movimento, e a coletividade disciplinada se forma cada vez mais escrava de si mesma.

Michel Foucault ao refletir sobre o poder caracteriza-o diferentemente daquilo que se diz. Postula que ele não é como uma coisa nem como propriedade, não está em um lugar específico, num indivíduo ou exclusivamente numa instituição, mas circula no meio social. E desmitifica ainda a ideia que se tem de um poder exclusivo do governo ou do Estado. De acordo com ele (1979, p. 182):

Trata-se [...] de captar o poder nas suas extremidades, em suas ramificações, lá onde ele se torna capilar; de captar o poder nas suas formas e instituições mais regionais e locais, principalmente no ponto em que ultrapassando as regras de direito que o organizam e delimitam [...] captar o poder na extremidade cada vez menos jurídica de seu exercício. 
O poder vai muito além daquilo que se conhece, permeando os corpos e transformando-os completamente. Quando no percorrer da história acontecem transformações nos modelos de punição para atos delituosos desde os suplícios até o sistema de prisão no século XIX, se confirma essa ideia; uma tentativa constante de enquadrar o indivíduo, de ostentar um poderio uno, de poder absoluto na vida de cada indivíduo, de docilizar e disciplinar a comunidade.

O sistema prisional serve de base para as pesquisas analíticas do filósofo, o que é de suma importância para seu trabalho. Por isso demonstra com o panóptico ${ }^{1}$ como os indivíduos são facilmente coagidos pelo poder invisível a eles, como se comportam ao saberem que estão sendo observados, e também com os suplícios. A ação do poder nega uma força que simplesmente pune fisicamente, mas que também vigia e controla. Dessa forma, Foucault postula também a questão dos saberes, dos micropoderes que operam na vida dos indivíduos, caracterizando um poder disciplinar, o qual controla os corpos, tendo como consequência uma sociedade organizada: trata-se, portanto, do nascimento do Biopoder.

Conhecer e sujeitar, saber e comandar são palavras que estão intimamente ligadas. Por um grande período da história o poder do soberano decidia sobre a vida e a morte, essa forma jurídica fazia com que ele tivesse o direito de um governante, apoderando-se dos corpos, do tempo, das coisas e da própria vida do sujeito. Tal poder permaneceria até ser deslocado do soberano para o Estado, o que segundo Foucault estaria posto ao nível da vida, ou seja, do "biopoder", da "biopolítica". O Estado, por conseguinte, é aquele que busca enquadrar o corpo humano, as suas forças, para integrá-lo em aparelhos eficientes operando diretamente sobre a vida. Para se obter um controle constante e o melhor funcionamento do aparelho, os corpos passaram a serem vistos como mecanismos de vida (nascimento, morbidade, mortalidade, longevidade etc.), sendo treinados e domesticados.

Pode-se dizer que, em suma, houve uma superação do poder soberano pela ação diretamente incidida na vida, o Biopoder, que caracteriza uma sociedade organizada e precisa para sua atuação efetiva, através da norma, da disciplina, da regularização. Trata-se de um plano político biológico, uma ação certeira que explicita a máxima do "fazer viver".

\footnotetext{
${ }^{1}$ Termo elaborado pelo Filósofo Jeremy Bentham (1748-1832) que, segundo ele, era um plano de organização arquitetural das prisões a fim de submeter os prisioneiros a uma vigilância permanente e poder reinseri-los no sistema produtivo. O Panóptico: é uma máquina de dissociar o par ver-ser visto: no anel periférico, se é totalmente visto, sem nunca ver; na torre central vê-se tudo, sem nunca ser visto [...] ele induz no detento um estado consciente e permanente de visibilidade que assegura o funcionamento automático do poder. (FOUCAULT, 1997, p. 178).
} 


\section{Análise do poder em Michel Foucault: do que foi ao que é}

O homem alienado pela concepção que se constituiu do poder, como instrumento, forma de dominação, exclusividade dos maiores, característica única do Estado e outras inúmeras definições que foram sendo introduzidas no seu pensamento, assumiu determinados conceitos como verdadeiros. Nisso, sendo compelido a essa aceitação passiva, tais compreensões tornaram-se ameaçadoras para a reflexão filosófica, análise históricogenealógica e fundamentação conceitual do poder.

Entretanto, com Michel Foucault, filósofo contemporâneo, a palavra poder adquire outra perspectiva, entendendo-a como microfísica, ou seja, uma gama de redes que permeia toda a vida social e particular do indivíduo. A filosofia foucaultiana desvela as abrangências tidas como exatas da palavra "poder", assumindo assim um caráter genealógico e analítico quanto às diversas formas de exercício do poder pelos tempos. Foucault desmistifica a ideia única de poder que coage, para abrir um amplo pensamento que vai muito além do senso comum. O filósofo aponta desde os suplícios até os sistemas punitivos da contemporaneidade uma relação permanentemente intrínseca entre conhecer e dominar, saber e comandar, que pode ser observada nos inúmeros meios que funcionam como um sistema de adestramento, numa tentativa constante de enquadrar o indivíduo no sistema que vigora a cada época.

Destarte, foi composta uma história de inúmeras microfísicas que compõe a ligação entre saber e poder que permeia os muros da teoria, agindo assim no campo social (FOUCAULT, 2005, p. 70). A microfísica deve ser entendida como micropoderes, porque o poder que emanava do soberano, da Igreja, ou de qualquer outro ente ou instituição única foi deslocado e ampliado numa relação extensa de alienação da mente, repressão, disciplina, submissão aos saberes, tentativa de readaptar o sujeito para que caiba no sistema, agindo diretamente na vida, assumindo assim caráter biológico.

A relação do poder/coerção sempre esteve presente na história, registrando nela um conto medonho de dominação e submissão, vida e morte, ações positivas e negativas, seja individual e/ou grupal. Ora nas mãos dos absolutistas, emanado do soberano, ora nos sistemas carcerários e nas diversas instituições, no próprio Estado, enfim, na natureza do início da constituição de comunidades humanas.

O poder absoluto destaca-se quando, no início da história das relações de poder, é visto como característico de retirar a vida ou conservá-la. Tal poder mantinha a severa, porém, 
comum, relação de submissão do escravo ao seu senhor. A dominação por um só homem pelo medo e pela passividade dos súditos fazia com que o soberano cada vez mais se demonstrasse e constituísse grande; por conseguinte, os súditos permaneciam numa relação igual entre eles mesmos, de pequenez e submissividade. A autoridade é independente do consenso dos súditos, é imposta. Acomodados pelo medo dos sistemas de punição que refletiam no poderio do soberano, os súditos não colocariam suas vidas à prova por conta de contestar ou não acatar alguma decisão soberana, outros, porém, por perceberem que a morte seria o caminho mais fácil para se libertar da escravidão do medo do absoluto, escolhiam-na como meio eficaz para resolução dos seus problemas, mesmo não sendo a morte interpretada como um protesto ou ato heroico.

A cerimônia do suplício era o ritual que evidenciava o soberano como detentor do poder marcando esse período. As penas eram as mais variadas possíveis e os castigos destinados de acordo com a hierarquia.

\begin{abstract}
A pena de morte natural compreende todos os tipos de morte: uns podem ser condenados à forca, outros a ter a mão ou a língua cortada ou furada e ser enforcados em seguida; outros, por crimes mais graves, a ser arrebentados vivos e expirar na roda depois de ter os membros arrebentados; outros a ser arrebentados até a morte natural, outros a ser estrangulados em seguida arrebentados, outros a ser queimados vivos, outros a ser queimados depois de estrangulados; outros a ter a língua cortada ou furada, e em seguida queimados vivos; outros a ser puxados por quatro cavalos, outros a ter a cabeça cortada, outros enfim a ter a cabeça quebrada. (FOUCAULT, 1997, p. 33).
\end{abstract}

Com a liturgia do suplício era demonstrado publicamente que o condenado não cumpriu com seus deveres de subordinado, negando a vontade do soberano. O corpo tornavase tela visível para que todos pudessem acompanhar a perversidade manifestada no insolente pela força física. Uma maneira bárbara de ratificar a mensagem a ser transmitida. O não cumprimento da vontade do soberano acarretaria no igual ou no pior ato.

Não obstante as formas de dominação, na Idade Média a Igreja Católica passa a exercer o papel de grande soberana. Ela tentará enquadrar os pecadores na doutrina cristã. Também a Igreja irá compor formas punitivas, como a inquisição, para a dominação. O poder espiritual alcançará seu cume com o poder papal, o sumo pontífice entre Deus e os homens, tornando-se demasiadamente grande, em extensão e no número de fiéis. O poder é emanado do sucessor petrino em razão da plenitudopotestatis $^{2}$. A questão do poder é inteiramente voltada para

\footnotetext{
${ }^{2}$ De acordo com o Dicionário de Filosofia Nicola Abbagnano a plenitudopotestatis é a soberania absoluta do papa sobre todos os homens, inclusive os príncipes, os reis e o imperador.
} 
Deus e suas implicações teocêntricas, podendo ser destacada aqui a necessidade que o governo tinha de manter-se através da cultura teocrática, ou seja, do poder divino, afinal, o Rei era um subordinado de Deus.

\footnotetext{
Certamente, na Idade Média ou na Antiguidade Greco-romana, sempre existiram tratados que se apresentavam como conselhos ao príncipe quanto ao modo de se comportar, de exercer o poder, de ser aceito e respeitado pelos súditos; conselhos para amar e obedecer a Deus, introduzir na cidade dos homens a lei de Deus, etc. (FOUCAULT, 2005, p. 277).
}

Embora o poder espiritual da Igreja tenha exercido um grande poderio em relação aos fieis, com o advento da modernidade surge também outras novas formas de exercício do poder, o disciplinar e o político. Destaca-se o poder disciplinar no campo individual e sociedade estatal num âmbito coletivo. Por conseguinte, o poder disciplinar surge justamente para sobrepor-se ao poder pastoral (exercido pelo pastor) que deveria conhecer, doar-se ao ponto de sacrificar sua vida pela salvação do outro. No campo político a sociedade estatal ocupa o lugar do poder soberano. Mais do que caracterizar esses dois âmbitos é perceber que o que nasce da lacuna é o poder disciplinar.

Assim sendo, o processo de adestramento do corpo como meio eficaz para tornálo dócil ao sistema foi a saída encontrada para desempenhar o poder. De certo modo, quando exercida no corpo, a disciplina adquire forças porque se torna útil. Porém, também poderá perder forças quando se torna sujeita a obedecer à política. O poder não é mais aquele de caráter estilhaçador do corpo, mas assume controle sobre esse corpo que é agora subtido à vigilância e punição.

Nesse sistema destaca-se o panóptico, que contribui para a análise do poder disciplinar, haja vista que, segundo o filósofo (1997, p. 180), ele "funciona como uma espécie de laboratório de poder. Graças a seus mecanismos de observação, ganha em eficácia e em capacidade de penetração no comportamento dos homens [...]". Agindo assim como forma de inibir o comportamento dos sujeitos, aprisionando-os no medo, limitando-os a agir normalmente, enfim, domando o "ser homem" para uma aceitação pacífica dos discursos de verdades que a sociedade tem como modelo, ditando comportamentos, valores, o que é correto e o que é errado.

Contudo, a industrialização e por consecutivo o capitalismo fezeram com que o avanço científico acarretasse no desenvolvimento de novos saberes. A psicologia, a sociologia, economia, história e geografia são exemplo desses saberes nascentes. Estes 
permearão de tal forma a vida individual e social do sujeito que retardará seu pensar, ou seja, influenciará em todas as suas atitudes, em seus costumes, enfim, na maneira de expressar a linguagem.

O poder se encontrará disseminado em todas as esferas da sociedade, atingindo a família, as instituições religiosas, educativas e econômicas, as práticas culturais e também as instituições do Estado, é difundido em todo o corpo social. O governo, com o auxílio das ciências, tentará organizar a sociedade. Ocorre que agora se exaltará a arte de governar como meta-habilidade, ir além das habilidades, cada um pode exercer o poder nos diversos âmbitos, sendo também obejeto de poder e assim sucessivamente. Ao mesmo tempo em que governam são governados, que ensinam são ensinados, que punem são punidos, que estudam são também estudados e assim sucessivamente.

Nasce também a prisão, e com ela o poder judiciário. Os detentos podiam ser estudados, a sociedade exerce poder sobre eles. A relação íntima acima descrita de poder e saber são explícitos porque conduz a um maior entendimento, bem como maior controle sobre os detentos.

Tudo isso permite ao poder se constituir mais humano e concreto, porém múltiplo, fluente, homogêneo, não concentrado, amplo. Não mais emanado de um único ente que seja ele humano ou transcendente, ou entendido como característica única do Estado entre outras definições que se concebiam positivas. Esse poder transita entre a base e o cume da sociedade, permeando-a. Não sendo algo outorgado, mas fruto de relações de poder, ou seja, é na convivência com os outros, nas relações sociais que ele passar a existir. Também para que o poder seja estabelecido faz-se necessária a força, que não seja ela somente a física, porque sua imposição sobre o corpo fere o homem no físico e psicológico, sujeitando-o ao medo acomodado, gerando corpos dóceis.

\section{As características do poder disciplinar a partir de suas técnicas na formação de corpos dóceis}

A característica do poder é expressamente visível quando na história a ação do soberano demonstrada através dos suplícios reafirma a ideia que se tem atualmente de tentar enquadrar o indivíduo no sistema. Através da leitura que se pode fazer, no suplício está a maior forma de expressão do poder disciplinar, servindo de princípio e base para a 
estruturação da forma de vigiar e punir durante os tempos. Ao docilizar o corpo, e consequentemente o sujeito, torna-se a coletividade obediente e pacífica, alcançando seus determinados fins.

O fundamento dos atos ostensivos de suplício era, contudo, a necessidade de manter uma organização piramidal na qual existiam duas camadas, numa estava o Soberano, em outra seus subordinados. A desobediência se torna visível no indolente que recebe como pena a morte dolorosa por partes, presenciada pelo público que a recebe como mensagem de ordem. Trata-se de um traço político no qual o crime ataca particularmente o próprio soberano, afinal, a força da lei é a sua própria vontade. A punição jurídico-política dos suplícios se alterava de acordo com os crimes cometidos, no entanto, com o protocolo previsto pela justiça, em que necessitaria ser um sofrimento lento e agonizante, como Foucault prescreve:

\footnotetext{
Utilização de suplícios "simbólicos", que a forma da execução faz lembrar a natureza do crime: fura-se a língua dos blasfemadores, queimam-se os impuros, corta-se o punho que matou; às vezes faz-se o condenado ostentar o instrumento de seu crime [...] reprodução quase teatral do crime na execução do culpado: mesmos instrumentos, mesmos gestos. Aos olhos de todos, a justiça faz os suplícios repetirem o crime, publicando-o em sua verdade e anulando-o ao mesmo tempo na morte do culpado. (FOUCAULT, 1997).
}

A prática se resume numa amostra do inferno, na morte do corpo para a libertação da alma, esta alcança a salvação concretizando a promessa de perdão segundo a moral cristã. $\mathrm{O}$ corpo, por sua vez, reproduzindo a veracidade do crime, é objeto onde o poder se concretiza e a ação do soberano é imediata e direta sobre ele uma vez que o indolente o fere pessoalmente como príncipe. Ainda que o corpo seja desprezado, nele é que se realiza a amplitude do poder e da força do príncipe, onde o suplício reconstitui sua magnitude ferida pela desobediência.

Quanto à organização social, o suplício funciona como um fator equilibrante na constituição daquela. A força física, característica maior do poder, é exercida sobre o corpo, manifestando a superioridade e eficácia do poder soberano. Toda essa liturgia da punição demonstra politicamente o direito e o poder que dela emanam, fazendo com que a moral se dissemine e seja cumprida em favor da vida.

Apesar disso, a estranheza e a cólera de um povo que, se sentindo mal com a tirania, sede de vingança e o exagero de crueldade das punições, reivindicou para si o obséquio de práticas novas. A justiça criminal ao invés da vingança adota o punir, devendo-se formular um novo direito, uma forma inovada necessariamente urgente, como maneira de extinguir o suplício, como se pode constatar neste fragmento (1997, p. 60) "Que as penas sejam 
moderadas e proporcionais aos delitos, que a de morte só seja imputada contra os culpados assassinos, e sejam abolidos os suplícios que revoltam a humanidade". O corpo recebe mais poderes porque além de um sistema de direito com novas penas e estruturas, a pessoa do soldado, por exemplo, torna-se um ícone daquilo que se pode ter como certo. É no corpo que se treina para obedecer, que se manipula para responder, enfim que multiplica suas forças (FOUCAULT, 1997, p.125). O homem se torna máquina e deve se adaptar num sistema mecânico de sobrevivência. Ao ser transformado, ajustado e utilizado, o corpo se torna dócil. Portanto, trabalhar o corpo nos seus detalhes, se torna condição suficiente para exercer uma força coercitiva sobre ele, monopolizando-o. Nessa relação, a força da disciplina impera como enquadramento do indivíduo no aparelho. Podem-se criar métodos e com eles um controle completo do corpo.

O momento histórico das disciplinas é o momento em que nasce uma arte do corpo humano, que visa não unicamente o aumento de suas habilidades, nem tampouco aprofundar sua sujeição, mas a formação de uma relação que no mecanismo o torna tanto mais obediente quanto é mais útil, e inversamente. (FOUCAULT, 1997, p. 127).

Com o surgimento do poder docilizador do corpo, nascem igualmente instituições que adotam esse sistema mecânico, adaptador e monopolizador. De um lado é possível perceber que a disciplina produz submissividade, aumento da força útil e também diminui a força no que tange à política de obedecer. As instituições serão orientadas por essa singularidade. São elaboradas técnicas, regulamentos e normas para o controle e dominação, que ao se tornarem cada vez mais comuns tornam-se também invisíveis, não perdendo sua permeabilidade em nível macro. A ordem social dependerá do poder coator no corpo do indivíduo para colocá-lo em seu devido lugar, caracterizando assim uma coletividade acéfala em sua monotonia. Quanto mais distribuída estiver essa coletividade em partes diferentes melhor será para o sistema que busca justamente na separação e ordenação das partes um meio eficaz para melhor exercer sua força, sua disciplina, enfim, para governar.

O que o sistema teme é a união dos diferentes. A força emana dessa união que de tão rica derrubá-lo-ia facilmente. A vigilância e o controle são imprescindíveis para o bom funcionamento do processo de docilização do corpo. Um exemplo particular disso é o modelo do panóptico de Jeremy Bentham. Um olho que tudo vê é ponto eficiente para impulsionar a prática de disseminação do poder como ação corporal. O sujeito é consciente de que está sendo observado e procura nos ínfimos detalhes de sua vida não errar porque sabe que será 
corrigido e punido até aprender que seu lugar é onde se obedece, enquadrando perfeitamente na verdade de um sistema. A correção pelo vigiar torna o indivíduo tão dócil que seu estágio regride ao nível animal quando o medo se transforma em instinto. Uma vez que a reflexão é inibida, pois, por sua vez se aparenta desorganizada e fora daquilo que se pretende obter, que é o exato ordenamento pela subordinação. Criam-se muitos personagens, divinizam ainda mais o que já é divino, atribuindo poder de castigar. Portanto, acomodar com a situação vigente é um meio certeiro para que a engrenagem do aparelho coator gire mais perfeita e mais rápida. É um círculo complexo de dependência, entendendo-se que inexiste a chance de entrar em outro sistema em que isso seja lenda.

\begin{abstract}
A disciplina "fabrica" indivíduos; ela é a técnica específica de um poder que toma os indivíduos ao mesmo tempo como objetos e como instrumentos de seu exercício. Não é um poder triunfante que a partir de seu próprio excesso, pode-se fiar em seu superpoderio; é um poder modesto desconfiado, que funciona a modo de uma economia calculada, mas permanente. [...] O sucesso do poder disciplinar se deve sem dúvida ao uso de instrumentos simples: o olhar hierárquico, a sanção normatizadora e sua combinação com um procedimento que lhe é específico, o exame. (FOUCAULT, 1997, p. 153).
\end{abstract}

Uma vigilância imponente presume um adestramento completo dos corpos. O poder disciplinar procura na divisão, análise e separação, extrair aquilo que é de mais característico do sujeito, tornando-o membro de uma massa fortemente domada, capaz de obedecer a um desconhecido que a conhece singularmente. Aos poucos o poder da disciplina vai se permeando na vida do indivíduo e dela se apropria, adestrando o corpo para melhor recolocálo, agora ensinado, no seu devido lugar.

Nesse modelo de docilização, alinhamento e adequação, surge no fim do século XVI e princípio do século XIX a prisão, como estratégia de exclusão do delinquente da comunidade para curá-lo e reintegrá-lo no convívio social. A própria massa se encarrega agora de puni-lo, o criminoso não é somente o que fere a vontade soberana, mas a moral e a ética social, comunitária. Destarte, o sujeito deve se adaptar a uma nova comunidade, às normas e disciplina que o aparelho corretivo prisional impõe. De acordo com Foucault (1979, p. 199), “o que agora é imposto é a justiça penal como seu ponto de aplicação, seu objeto "útil”, não será mais o corpo do culpado levantado contra o corpo do rei; não será mais tampouco o sujeito de direito de um contrato ideal; mas o indivíduo disciplinar".

O regime penal apresenta aspectos antagônicos no sentido de, por um lado, o policiamento tático, cauteloso, que controla a insubordinação, impondo assim o mecanismo 
de disciplina individualizante. Também através da universalidade do controle disciplinar que o permite conhecer seu próprio ideal, bem como fabricar mecanismos de poder. Assim o preso adota uma personalidade, um comportamento de fachada que se destina a manter as impressões do sistema corretor (AZEVEDO, 1999, p.29).

Aprisionado numa comunidade reclusa, o indivíduo deve ser reformado integralmente pelos poderes que emanam dessa instituição. A disciplina aplicada deve ser suficientemente coercitiva ao ponto de, ininterruptamente, converter pela imposição o criminoso que feriu a ética comunitária, levando-o à ressocialização. Assim a liberdade que possui se caracteriza na mesma dos outros delinquentes, porque está nas normas, é parcial e incompleta, resumindo-se na limitação dos corpos. Quando se trata dos sentimentos, o que prevalece é a solidão, pois ela traz consigo a reflexão do mal cometido e promove o remorso. Viver isoladamente em relação à vida fora da prisão torna a pena individualizante e, por sua vez, mais ativa, produzindo resultados desejados. É o encontro do criminoso com o poder que exerce sobre ele mesmo. Se o trabalho é condição suficiente para considerar um homem digno, logo, num sistema que procura reinserir honradamente um sujeito no seio social, deverá adotar o trabalho, juntamente com o isolamento, como agente de transformação correcional.

O trabalho penal pode requalificá-lo, não necessariamente de uma maneira lucrativa, contudo, para coadunar com a relação de poder que, economicamente não avança do zero. É parte integrante de uma total submissão que na solidão, individualidade e serviço se enquadra em um aparelho de produção. Como o filósofo conta em sua obra:

O trabalho penal deve ser concebido como sendo por si mesmo uma maquinaria que transforma o prisioneiro violento, agitado, irrefletido em uma peça que desempenha seu papel com perfeita regularidade. A prisão não é uma oficina, ela é, ela tem que ser em si mesma uma máquina de que os detentos-operários são ao mesmo tempo as engrenagens e os produtos; ela os "ocupa" e isso continuamente, mesmo se fora com um único objetivo de preencher seus momentos. (FOUCAULT, 1997, p. 216).

O sistema carcerário demonstra-se imponente e magnânimo, revestido de um poder invisível e fluente. Agindo corriqueiramente, ele acalma a comunidade normal dos bons e pune, disciplinando e enquadrando o indivíduo da sociedade dos ladrões e criminosos, os maus. A prisão é um meio certeiro e exemplo perfeito para ilustrar um dos meios pelo qual o homem contemporâneo se molda no âmbito social, coletivo e particular. O poder da disciplina qualifica um novo ser do homem, modelado, assistido, recolocado, superlotado de preconceitos. 
Por conseguinte, quando se olha para a história percebe-se a mudança de eixo, da moral e da ética, variações de poderes, destarte o que permanece é o que eles implicam: enquadrar-se. Essa reflexão se estende às sociedades que observadas pelo olho visível do poder são obrigadas a se submeter diante de um poder coercitivo que as transforma. $\mathrm{O}$ mesmo acontece com cada indivíduo, que se abre, involuntariamente, à permeabilidade dos poderes em sua própria vida, ou seja, a um Biopoder.

\section{O Biopoder como forma de organização social}

Ao observar a genealogia da história, intui-se que o poder está mais vivo e eficaz. Não obstante, a cada tempo ele assume meios para adentrar e se definir indelével na sociedade, de maneira que ela não possa ser puramente indiferente a ele. A vida assume o predicado do sujeito poder, e forma uma frase validada pelo discurso que se criou em relação à fonte do poder e a direção na qual ele prossegue, desde o sistema prisional, na tentativa de docilização dos corpos e reinserção comum dos indivíduos, até a maneira atualizada de se apoderar da vida de cada sujeito particular e, consequentemente, de um todo.

Aquele poder que manifestava sua força no direito de decidir sobre a vida e a morte dá lugar a outro tipo de poder, este se manifesta concretamente por meio da gestão da vida, permitindo assim que o velho direito de "fazer morrer ou deixar viver" possa dar lugar ao poder de "fazer viver e deixar morrer". Contudo, a morte, até então o ponto máximo da manifestação do poder passa a ser o momento que lhe escapa (FONSECA, 2012, p. 74-75). Segundo Michel Foucault (2005, p. 132)., da orientação do poder disciplinar individualizante para o poder regulamentador que age no coletivo como biológico "abre-se, assim a era de um 'bio-poder'”.

Este poder sobre a vida teria podido se organizar concretamente, a partir do século XVIII, segundo dois eixos principais. O primeiro deles teria se centrado sobre o corpo dos indivíduos, o corpo capturado como objeto de intervenção, o corpo como máquina [...]. O segundo eixo, formado um pouco mais tarde, centrou-se no corpo como espécie, o corpo transpassado pela mecânica da vida e suporte de processos biológicos, tais como os nascimentos, a procriação, as mortes, as doenças, a longetividade. (FONSECA, 2012, p. 75). 
Ao entender esse poder que constantemente está em movimento, Foucault percebe conjuntamente uma nova perspectiva da ação do poder nas sociedades modernas. $\mathrm{O}$ homem ocidental deve-se instruir aos poucos a ser uma espécie viva num complexo mundo vivo. Deve se dar conta das condições de sua existência, do seu corpo, da probabilidade de vida e saúde individual e comunitária, isso permite que as forças se modifiquem num espaço onde se pode dividi-las e melhor enquadrá-las (FOUCAULT, 2005, p. 134). É na tentativa de instituições como o Estado, que procurando gerir e garantir a vida para dela se apoderar e controlar, que o poder se expressa. De tal maneira, utiliza como definição desse poder que age em nível biológico a palavra "Biopoder", como conceito para tratar das diversas abrangências que a palavra dispõe. Perceber a vida como meio dinâmico para atuação do poder é garantir progresso e política. Por conseguinte, tem-se uma atuação do plano político no biológico.

\begin{abstract}
O fato de viver não é mais esse sustentáculo inacessível que só emerge de tempos em tempos, no acaso da morte de sua fatalidade: cai, em parte, no campo de controle do saber e de intervenção do poder. Este não estará mais somente a voltas com sujeitos de direito sobre os quais seu último acesso é a morte, porém com seres vivos, e o império que poderá exercer sobre eles deverá situar-se no nível da própria vida; é o fato do poder encarregar-se da vida, mais do que a ameaça da morte, que lhe dá acesso ao corpo. [...] O homem, durante milênios, permaneceu o que era para Aristóteles, um animal vivo e, além disso, capaz de existência política; o homem moderno é um animal, em cuja política sua vida de ser vivo está em questão. (FOUCAULT, 2005, p.134).
\end{abstract}

Para a contemporaneidade o biopoder foi um elemento imprescindível quanto à ascensão do capitalismo. Este pôde somente ser preciso numa inserção controlada dos corpos no aparelho de produção e, contudo, um ajustamento dos fenômenos de população aos processos econômicos (FOUCAULT, 2005, p. 132). Para o contínuo crescimento do capitalismo, foi necessário docilizar ainda mais as massas, agregando-as num único pensamento alienante de busca por felicidade, o que na verdade se resume numa utilizabilidade causada pelos métodos de poder que caracterizaria tanto a força, o desenvolvimento de aptidões, quanto a própria vida. Trata-se de um "ajustamento da acumulação dos homens à do capital, a articulação do crescimento dos grupos humanos à expansão das forças produtivas e a repartição diferencial do lucro" (FOUCAULT, 2005, p. $133)$.

O biopoder se desenvolve também pelo desempenho da norma. Ele "não se constitui numa forma de poder independente do poder disciplinar, mas é integrado por este último. [...] se concretizaria pelo investimento sobre a vida e seus fenômenos, mecanismo que teria no 
'corpo vivo' e na 'vida enquanto processo' seus dois vetores principais.” (FONSECA, 2012, p. 75). É a necessidade de um poder que age na vida para regular e manter um controle sobre ela. Como Foucault identifica (2005, p. 135).

\begin{abstract}
Um poder dessa natureza tem de qualificar, medir, avaliar, hierarquizar, mais do que se manifestar em seu fausto mortífero; não tem que traçar a linha entre súditos obedientes dos inimigos do soberano, opera distribuição em torno da norma. [...] a lei funciona cada vez mais como norma, e que a instituição judiciária se integra cada vez mais num contínuo de aparelhos (médicos, administrativos etc.)cujas funções são sobretudo reguladoras. Uma sociedade normalizadora é o efeito histórico de uma tecnologia de poder centrada na vida.
\end{abstract}

Com o desenvolvimento do Biopoder, a norma se faz indelével, permeando todo o corpo social, confirmando a lei e com ela o sistema jurídico. A abordagem que agora deve ser pensada é a norma como mecanismo de intervenção do poder, ou seja, trata-se de pensar nos mecanismos de normalização (FONSECA, 2012, p. 62). A lei é caracterizada pela fatalidade do seu não cumprimento que gera a morte como instância máxima de punição, já que ela necessita da vida para se apoderar. Como Foucault explicita (2005, p. 135), "já não se trata de pôr a morte em ação no campo da soberania, mas distribuir os vivos em um domínio de valor e utilidade”. O poder da norma também está centrado na organização, no aproveitamento, na hierarquização que se manifesta no âmbito coletivo regularizando a sociedade à lei que lhe foi aceita irrefletida. Com isso a soberania da lei delimita o espaço do biopoder num nível macro de ação, normalizando a sociedade, criando corpos dóceis.

A norma se torna um meio certeiro para conseguir os objetivos do poder, juntamente com a normalização configura uma sociedade adequada, um corpo que pode ser mais bem explorado. A sociedade moderna de normalização é fruto tanto da disciplina quanto da regulamentação, não podendo sobrepor-se uma à outra, nem mesmo ressaltar a influência e as características de uma exclusivamente, pelo fato de estarem atreladas, são fundidas. Em tudo a norma se faz presente, seja nas técnicas (de produção, consumo, etc.) ou política (regularização das esferas sociais pelo Estado, etc.). Isso traça um plano lógico de domínio macro na sociedade, na qual ela (a norma) é aplicada diretamente no corpo e, por imediato, na vida, regulamentando o ser comunitário. "A norma é o que pode tanto se aplicar a um corpo que se quer disciplinar quanto a uma população que se quer regulamentar" (FOUCAULT, 2000, p. 302). Por conseguinte, a sociedade de normalização se caracteriza por ser uma sociedade em que se cruzam a norma da regulamentação e a da disciplina. 
A norma produz objetividade. É um princípio de comunicação, uma maneira, particular para resolver o problema da intersubjetividade. A norma equaliza; torna o indivíduo comparável a cada outro; fornece a medida.Se dar normas é classificar, é em primeiro lugar porque a norma estabelece classes de equivalência.Mas a norma des-equaliza do mesmo modo. É aliás, a única objetividade que nos dá: a norma convida o indivíduo a reconhecer-se diferente dos outros; encerra-o no seu caso, na sua individualidade, na sua irredutível particularidade, Precisamente, o normativo afirma tanto mais a igualdade de cada um perante todos quanto infinitiza as diferenças. (FOUCAULT, 2000, p. 108-109).

Nesse sentido, o sexo surge também como expressão desse poder e como mira das disputas políticas. No século XIX o sexo é desmembrado e refletido mais explicitamente nos assuntos, revelado pelos saberes que lhe atribuiram e confirmaram um caráter individual, promíscuo e vulgar que lhe foi delineado. Por consecutivo, também se faz presente nos ramos de operações políticas, tentando o freio da procriação, apelando à campanhas de moralização e responsabilização. Como o filósofo ressalta:

É que ele se encontra na articulação entre dois eixos ao longo dos quais se desenvolveu toda a tecnologia política da vida. De um lado, faz parte das disciplinas do corpo: adestramento, intensificação e distribuição das forças, ajustamento e economia de energias. Do outro, o sexo pertence à regulação das populações, por todos os efeitos globais que induz. Insere-se simultaneamente nos dois registros; dá lugar a vigilâncias infinitesimais, a controles constantes a ordenações espaciais de estrema meticulosidade, a exames médicos ou psicológicos infinitos, a todos um micropoder sobre o corpo; mas, também, dá margem a medidas maciças, a estimativas estatísticas, a intervenções que visam todo o corpo social ou grupos tomados globalmente. O sexo é acesso, ao mesmo tempo, à vida do corpo e à vida da espécie". (FOUCAULT, 2005, p. 137).

Tudo o que está relacionado à vida é parte essencial na constituição do Biopoder, o sexo traz consigo a ideia de proliferação da vida, reforça o ser da espécie. A sexualidade se atualiza na contemporaneidade justamente por esses princípios de poder exercido no grupo, ora pela norma, ou pelo saber, ou pelas disciplinas e regulamentações, em suma, no sentido de se apoderar da vida, sendo que a sexualidade se une a esses dispositivos. O biopoder se configura nesse conjunto multifacetado de forças que tem a sua ação não em um corpo individual. Não está para o particular, mas para o todo, e sua ação é concretude que, coordenada pelos Estados Modernos, faz dessa biopolítica um instrumento poderoso de conhecer a comunidade que se tem a submeter. A técnica vem pela história que tentou enquadrar, punir, docilizar e trasformar os indivíduos, contudo, se faz num corpo, um corpo, maiormente chamado de sociedade que adquire o atributo de disciplinada. 
A dominação é invisível ao homem que vai se enquadrando aos poucos no sistema ao qual se quer chegar, sempre da instância maior emana o poder mesmo sendo objeto dele, o que o torna diferenciado é justamente a ação na vida que monopoliza todo o corpo e o faz subjulgado a essa instância máxima que recebe na maioria das vezes o nome de Estado. Apossar-se do corpo, conhecê-lo, dominá-lo e permitir que ele sobreviva é condição suficiente para que a sociedade organizada se submeta à ação do Biopoder docilmente.

\section{CONSIDERAÇÕES FINAIS}

No desenvolver do trabalho nota-se que a história compôs um cenário eminentemente importante para a atuação do Biopoder. O poder não deve mais ser visto como uma forma única de ação, nem mesmo caracterizado como proveniente de uma única instituição. Ele não se faz visível para agir melhor na invisibilidade que dá sua concretude e o torna mais forte, talvez esse seja o motivo de se caracterizar múltiplo, ou seja, de sua ação ser na pluralidade. O poder não é concentrado nas mãos de um indivíduo sendo emanado dele mesmo.

Organizar a comunidade através de uma liturgia suplicial no medo pela ostentação da morte, tornou-se o símbolo da máxima do Soberano de decidir sobre a vida e a morte. Essa questão possibilitou que se entenda o medo como característico de um poder uno que emana de algum modo daquele que é maior. Medo de questionar, de replicar, medo de Deus, medos que trouxeram ao sujeito um estado de submissão que tão fortemente o dominou que possibilitou assumir uma concepção e interpretação do poder como simplesmente emanado do uno. Tal visão se mostra lacunar quando a partir de Michel Foucault entende-se o poder como um processo, múltiplo, singular, porém não contido, ilimitado, expressado no mundo por uma gama de formas, advindo por todos os lados, permeando tanto o indivíduo quanto o corpo social. A disciplina se expressa como meio eficiente para a organização de um povo e com ela os saberes, os preconceitos, a norma, a justiça, o Estado, as instituições que têm como objetivo enquadrar o indivíduo, restabelecê-lo, transformá-lo e solidificá-lo na submissão.

O biopoder surge não para eliminar as técnicas, as normas, a lei, mas pelo contrário, para afirmá-las. Afirmá-las na vida. A união da disciplinalização dos corpos com a regulamentação é a chave para uma sociedade organizada pelo Biopoder. O mundo moderno se constitui por todas essas características, a sociedade é normativa, bem enquadrada e precisa, busca continuamente com sede a ciência, e se reconhece inconscientemente serva 
desta, afinal ela é um elemento substancialmente sólido no que diz respeito à garantia da vida e da espécie. O biopoder se constitui assim literalmente mais "vivo" abraçando toda a extensão da vida humana pela política do biológico, ou seja, uma era bio-política.

\section{REFERÊNCIAS}

AROPAllO, Maria Cristina. A presença de Nietzsche no discurso de Foucault. 2005. 115f. Dissertação (Mestrado em Filosofia) - Universidade São Judas Tadeu, São Paulo, 2005.

AZEVEDO, J. E. As relações de poder no sistema prisional. São Paulo, Revista da APG Associação de Pós Graduandos da PUC/SP, n.18, p. 29-35, 1999.

CASTRO, Edgardo. Vocabulário de Foucault: um percurso pelos seus temas, conceitos e autores. Tradução de Ingrid Muller Xavier; revisão técnica de Alfredo Veiga-Neto e Walter Omar Kohan. Belo Horizonte: Autêntica, 2009.

FONSECA, Márcio Alves. Michel Foucault e o Direito. 2.ed. São Paulo: Saraiva, 2012.

FOUCAULT, M. História da sexualidade: a vontade de saber. v.1. 16. ed. Tradução de Maria Thereza da Costa Albuquerque e J. A. Guilhon Albuquerque. Rio de Janeiro: Graal, 1999.

FOUCAULT, M. Microfísica do poder. 21. ed.Organização, introdução e revisão técnica: Roberto Machado. Rio de Janeiro: Graal, 1979.

FOUCAULT, M. Vigiar e Punir: história da violência nas prisões. 15. ed. Tradução Raquel Ramalhete. Petrópolis, RJ: Vozes, 1997.

RABINO, Paul; ROSE, Nikolas. O conceito de biopoder hoje. Política e trabalho, [ S.l. ], v.1, n.24, p. 19-37, 2006.

SOUSA, Washington Luis. Ensaio sobre a noção de poder em Michel Foucault. Múltiplas Leituras.v.4, p.1-2, fev. 2011. 